\title{
ANALISIS FAKTOR-FAKTOR YANG MEMPENGARUHI EKSPOR TEPUNG KELAPA SULAWESI UTARA
}

\author{
Julentia M. V. Makatita \\ Ribka M. Kumaat \\ Juliana R. Mandei
}

\begin{abstract}
The objective of this research is to analyze the influence of coconut production, the Rupiah exchange rate against the US \$, and the export prices of desiccated coconut to the volume of exports of desiccated coconut North Sulawesi. This research was conducted in March-May 2016, with the location of Manado City, North Sulawesi. The data used in this research is secondary data obtained from related agencies such as the Department of Industry and Trade in North Sulawesi, Central Agency Statistics in North Sulawesi,Indonesia Bank, andAgricultural Departmentof North Sulawesi.Besides, there were interviews conducted on one of the companies which exportedthe desiccated coconut in North Sulawesi, namely PT. Dimembe Nyiur Agripro, to support the secondary data that has been obtained. The variables measured in this research are coconut production (Kg/year), the Rupiah exchange rate against the US\$ (Rupiah), and desiccated coconut export price $(U S \$ / K g)$. Thedata used istime series in the period of 2006 - 2015. Thedata analysis used is multiple linear regression. The result of this research shows that significantly in the time period of 2006-2015 the coconut production has positive influence on exports of desiccated coconut. The exchange rate shows a positive tendency and the export prices show that there was negative impact tendency, though both are not significant statistically to the exports of desiccated coconut in North Sulawesi.
\end{abstract}

Keywords: factors, exports, desiccated coconut, North Sulawesi

\begin{abstract}
ABSTRAK
Penelitian ini bertujuan untuk menganalisis pengaruh produksi kelapa, kurs rupiah terhadap US\$ dan harga ekspor tepung kelapa terhadap volume ekspor tepung kelapa Sulawesi Utara. Penelitian ini dilaksanakan pada bulan Maret - Mei 2016 dengan lokasi Kota Manado Sulawesi Utara. Data yang digunakan dalam penelitian ini adalah data sekunder yang diperoleh dari instansi terkait seperti : Dinas Perindustrian dan Perdagangan Sulawesi Utara, Badan Pusat Statistik Sulawesi Utara, Bank Indonesia, dan Dinas Perkebunan Sulawesi Utara. Selain itu, dilakukan wawancara terhadap salah satu perusahaan yang mengekspor tepung kelapa Sulawesi Utara, yaitu PT. Dimembe Nyiur Agripro untuk mendukung data sekunder yang telah diperoleh. Variabel yang diukur dalam penelitian ini adalah produksi kelapa (Kg/tahun), kurs rupiah terhadap US\$ (Rupiah), dan harga ekspor tepung kelapa (US\$/Kg). Data yang digunakan adalah runtut waktu (time series) dengan periode tahun 2006 - 2015. Analisis data yang digunakan adalah regresi linier berganda. Hasil penelitian menunjukkan bahwa secara signifikan dalam periode waktu 2006-2015 produksi kelapa berpengaruh positif terhadap ekspor tepung kelapa. Kurs menunjukkan ada kecenderungan berpengaruh positif dan harga ekspor menunjukkan ada kecenderungan berpengaruh negatif walaupun secara statistik keduanya tidak signifikan terhadap ekspor tepung kelapa Sulawesi Utara.
\end{abstract}

Kata kunci: faktor-faktor, ekspor, tepung kelapa, Sulawesi Utara 


\section{PENDAHULUAN}

\section{Latar Belakang}

Setiap negara memiliki kekayaan alam masing-masing serta potensi untuk menciptakan produk yang memiliki comparative advantage (keunggulan komparatif) tersendiri, baik dari bahan baku, tenaga kerja maupun biaya yang dikeluarkan untuk membuat suatu produk tertentu. Oleh sebab itu, sangat penting diadakannya sistem perdagangan yang tidak hanya mengandalkan perdagangan dalam negeri saja, tetapi meluas sampai ke perdagangan internasional.

Indonesia selalu aktif terlibat dalam perdagangan internasional. Kegiatan ekspor menjadi perhatian utama dalam memacu pertumbuhan ekonomi Indonesia (Kaunang, 2013). Meskipun demikian, dalam empat tahun terakhir ini, ekspor Indonesia menunjukan perkembangan yang menurun. Dari sisi nonmigas total ekspor di tahun 2010 adalah sebesar $129.739,50$ juta US $\$$ dan mengalami kenaikan yang signifikan pada tahun 2011 menjadi $162.019,50$ juta US\$ dan terus mengalami penurunan dari tahun 2012 sampai 2015 menjadi $131.730,33$ juta US\$.

Dalam ekspor non migas ada tiga sektor yang berperan penting, yaitu sektor industri, sektor pertambangan dan sektor pertanian. Tabel 1 menunjukkan bahwa sektor industri memberikan kontribusi terbesar dalam ekspor non migas apabila dibandingkan dengan sektor pertambangan, sektor pertanian dan sektor lainnya. Sektor pertanian menempati urutan ketiga dalam memberikan kontribusi pada ekspor non migas Indonesia. Akan tetapi, ekpor sektor pertanian adalah yang paling stabil dibandingkan dengan sektor non-migas lainnya.

Sektor Pertanian merupakan sektor unggulan Sulawesi Utara. Dari lima sub sektor pertanian, perkebunan memegang peranan penting dalam perekonomian daerah karena memberikan kontribusi yang cukup besar. Luas areal perkebunan kelapa adalah yang terbesar dari seluruh tanaman perkebunan di Sulawesi Utara. Tahun 2012 luas perkebunan kelapa sebesar 250.141,65 kemudian meningkat tahun 2013 menjadi 278.599,53 dan terus meningkat hingga tahun 2014 mencapai luas areal $278.484,10$ ha. Kelapa merupakan komoditas perkebunan yang perkembangannya turun temurun tersebar di seluruh Nusantara khususnya di daerah Sulawesi Utara. Hampir seluruh bagian tanaman kelapa dapat dimanfaatkan sehingga tanaman kelapa dijuluki sebagai pohon kehidupan (tree of life).

Tanaman kelapa sangat bermanfaat baik untuk konsumsi sendiri maupun untuk keperluan bahan baku industri. Bahkan produk turunan kelapa sudah dimanfaatkan oleh produsen untuk tujuan ekspor karena memberikan kontribusi yang cukup besar untuk devisa Sulawesi Utara. Salah satu produk turunan kelapa yang menjadi andalan ekspor Sulawesi Utara saat ini adalah tepung kelapa.

Tepung Kelapa Sulawesi Utara saat ini memang makin diminati oleh masyarakat dunia. Mutu tepung kelapa sudah memenuhi standard sesuai dengan yang dipersyaratkan oleh negara pengimpor sehingga ada trend peningkatan permintaan tepung kelapa beberapa tahun terakhir oleh negara-negara tujuan ekspor.

Ekspor tepung kelapa Sulawesi Utara menempati urutan ke empat pada produk turunan kelapa andalan daerah dan menyumbangkan devisa yang cukup besar untuk Sulawesi Utara. Tepung kelapa Sulawesi Utara semakin diminati oleh pasar dunia namun, data 10 tahun terakhir menunjukkan bahwa terjadi fluktuasi pada ekspor tepung kelapa Sulawesi Utara maka sangat menarik untuk diketahui faktor-faktor yang mempengaruhi volume ekspor tepung kelapa Sulawesi Utara.

\section{Perumusan Masalah}

1. Apakah produksi kelapa mempengaruhi volume ekspor tepung kelapa Sulawesi Utara?

2. Apakah kurs rupiah terhadap US\$ mempengaruhi volume ekspor tepung kelapa Sulawesi Utara?

3. Apakah harga ekspor tepung kelapa mempengaruhi volume ekspor tepung kelapa Sulawesi Utara?

\section{Tujuan Penulisan}

1. Untuk menganalisis pengaruh produksi kelapa terhadap volume ekspor tepung kelapa Sulawesi Utara. 
2. Untuk menganalisis pengaruh kurs Rupiah / US\$ terhadap volume ekspor tepung kelapa Sulawesi Utara.

3. Untuk menganalisis pengaruh harga ekspor tepung kelapa terhadap volume ekpor tepung kelapa Sulawesi Utara.

\section{Manfaat Penulisan}

1. Untuk memberikan informasi kepada produsen, terkait dengan faktor-faktor yang berpengaruh signifikan terhadap volume ekspor tepung kelapa sehingga ekspor tepung kelapa Sulawesi Utara bisa lebih ditingkatkan.

2. Untuk para peneliti lain, diharapkan penelitian ini bisa menjadi salah satu rekomendasi untuk penelitian-penelitian selanjutnya.

\section{METODOLOGI PENELITIAN}

\section{Waktu dan Tempat Penelitian}

Penelitian ini dilakukan selama tiga bulan yaitu sejak bulan Maret sampai bulan Mei 2016 dengan lokasi Kota Manado Provinsi Sulawesi Utara.

\section{Metode Pengumpulan Data}

Data yang digunakan dalam penelitian ini adalah data runtut waktu (time series) dengan periode tahun 2006 - 2015. Dalam penelitian ini data-data yang digunakan data sekunder.

Data sekunder dikumpulkan dari beberapa instansi terkait seperti : BPS (Badan Pusat Statistik), BI (Bank Indonesia), Kementerian Perdagangan, Kementerian Pertanian, Dinas Perindustrian dan Perdagangan Sulawesi Utara, dan Dinas Perkebunan Sulawesi Utara serta dari berbagai buku dan literatur yang berkaitan dengan penelitian ini. Selain data sekunder, dilakukan juga wawancara terhadap salah satu perusahaan yang mengekspor tepung kelapa yaitu, PT DNA (Dimembe Nyiur Agripro) untuk menunjang data sekunder yang telah diambil.

\section{Konsep Pengukuran Variabel}

Variabel yang digunakan dalam penelitian ini meliputi empat variabel yang tersusun atas satu variabel terikat (Dependent Variable) dan tiga variabel bebas (Independent Variable). Variabel terikat dalam penelitian ini adalah volume ekspor tepung kelapa Sulawesi Utara sedangkan variabel bebas dalam penelitian ini adalah jumlah produksi kelapa Sulawesi Utara, Kurs rupiah terhadap US\$ dan harga ekspor tepung kelapa Sulawesi Utara.

1. Volume Ekspor tepung kelapa Sulawesi Utara adalah realisasi volume tepung kelapa yang dikirim ke luar negeri dalam satuan berat (Kg/Tahun)

2. Produksi kelapa adalah jumlah produksi kelapa yang diukur dalam satuan berat ( $\mathrm{Kg}$ /Tahun)

3. Kurs Rupiah terhadap US\$ adalah harga satuan mata uang dollar Amerika yang diukur dalam satuan mata uang (Rp)

4. Harga Ekspor tepung kelapa adalah harga yang terjadi antara eksportir dan importir yang diukur dalam satuan mata uang (US\$/Kg).

\section{Metode Analisis Data}

Analisis yang digunakam dalam penelitian ini adalah analisis regresi linier berganda dengan persamaan :

$$
\mathrm{Y}=\beta_{0}+\beta_{1} \mathrm{X}_{1}+\beta_{2} \mathrm{X}_{2}+\beta_{3} \mathrm{X}_{3}+\mu
$$

Keterangan:

$\mathrm{Y} \quad=$ Volume ekspor tepung kelapa Sulawesi Utara

$\mathrm{X}_{1}=$ Jumlah Produksi kelapa Sulawesi Utara

$\mathrm{X}_{2} \quad=$ Kurs Rp terhadap US\$

$\mathrm{X}_{3} \quad=$ Harga ekspor tepung kelapa Sulawesi Utara

$\beta_{0} \quad=$ Intersep

$\beta_{1}, \beta_{2}, \beta_{3}=$ Koefisien regresi

$\mu \quad=$ Kesalahan pengganggu yang disebabkan oleh faktor lain di luar model 


\section{HASIL DAN PEMBAHASAN}

\section{Gambaran Umum Lokasi Penelitian}

Sulawesi Utara merupakan salah satu daerah yang memiliki sumber daya alam yang sangat potensial. Kekayaan alam ini menjadikan sebagian besar penduduk Sulawesi Utara bekerja di sektor pertanian. Dari lima sub sektor pertanian, yaitu: perkebunan, tanaman pangan, kehutanan, perikanan dan peternakan, sub sektor perkebunan memegang peranan yang penting karena memberikan kontribusi yang cukup besar dalam perekonomian Sulawesi Utara.

Tanaman kelapa (Cocos nucifera Linn) tumbuh subur dan merupakan tanaman unggulan di Sulawesi Utara. Semua bagian dari tanaman kelapa sudah dimanfaatkan untuk menjadi berbagai produk olahan. Bahkan ada beberapa produk olahan dari kelapa yang sudah diekspor ke negara lain. Produk turunan kelapa ini diekspor hingga ke berbagai negara yang ada di benua Asia, Amerika dan Eropa.

Tepung kelapa (dessicated coconut) Sulawesi Utara merupakan salah satu produk andalan daerah yang diekspor dan diminati oleh negara pengimpor dibandingkan dengan produksi tepung kelapa dari daerah-daerah lain yang ada di Indonesia. Tepung kelapa Sulawesi Utara memiliki cita rasa yang khas karena lebih manis dan lebih gurih dari daerah lain serta sudah mampu memenuhi standar internasional yang dipersyaratkan.

Tepung Kelapa Sulawesi Utara sudah diekspor ke berbagai negara di belahan dunia. Dari data yang diambil dari Dinas Perindustrian dan Perdagangan Sulawesi Utara 10 negara yang menjadi tujuan utama ekspor tepung kelapa tahun 2015 antara lain: Belanda, Jerman, Brasil, Australia, Inggris, Rusia, Belgia, Selandia Baru, Mesir dan Polandia. Selain itu, di benua Eropa negara yang mengimpor tepung kelapa Sulawesi Utara adalah Italia, Yunani, Spanyol, Irlandia Utara dan Perancis. Di benua Amerika tepung kelapa diekspor ke Amerika Serikat, Argentina, Uruguay, Paraguay, Norwegia, Georgia, Chili dan lain-lain. Afrika Selatan, Ukraina, Korea Selatan, China, Taiwan, Vietnam dan Malaysia pun mengimpor tepung Kelapa Sulawesi Utara.

\section{Pembahasan Variabel}

Kegiatan ekspor mempunyai peranan yang sangat penting bagi perkembangan industri itu sendiri maupun bagi pemerintah. Perdagangan internasional dapat mendorong suatu negara untuk meningkatkan ekpornya keluar negeri sehingga dapat memicu peningkatan pertumbuhan ekonomi dan pendapatan nasional suatu negara.

Untuk dapat mengatahui faktor-faktor apa saja yang mempengaruhi besar kecilnya nilai ekspor suatu negara maka penelitian ini membahas variabel-variabel apa saja yang dapat mempengaruhi ekspor khususnya ekspor tepung kelapa. Faktor-faktor yang mempengaruhi tersebut antara lain produksi kelapa Sulawesi Utara, Kurs rupiah terhadap US\$ dan harga ekspor tepung kelapa.

\section{Produksi Kelapa Sulawesi Utara}

Untuk memproduksi tepung kelapa dibutuhkan pasokan bahan baku,yaitu kelapa. Kelapa yang dibutuhkan untuk membuat tepung kelapa adalah kelapa Dalam yang utuh dan tidak boleh pecah. Kelapa seperti ini dibutuhkan untuk menjaga kualitas dari tepung kelapa yang diminta oleh negara pengimpor. Kelapa yang pecah membuat kualitas dari tepung kelapa menurun. Namun, data produksi kelapa Dalam tidak tersedia sehingga data yang digunakan adalah total produksi kelapa Dalam dan Genja Sulawesi Utara.

Selain tepung kelapa ada berbagai produk olahan kelapa yang menjadi unggulan dan diekspor juga ke luar negeri. Data yang diperoleh dari Dinas Perindustrian dan Perdagangan menunjukkan bahwa selain tepung kelapa, produk olahan kelapa yang diekspor dan menjadi produk unggulan ekspor di Sulawesi Utara adalah minyak kelapa kasar, minyak goreng kelapa, asam lemak dari kelapa, kopra, bungkil kopra, dan arang tempurung. Bahan baku dari produk-produk ini adalah kelapa. Hal ini membuat persaingan antara perusahaan untuk memperoleh bahan baku menjadi ketat. Ada begitu banyak perusahaan dengan bahan baku kelapa yang membutuhkan pasokan kelapa. 
Permintaan tepung kelapa dari luar negeri selalu ada. Namun, persediaan atau produksi kelapa Sulawesi Utara belum mampu mencukupi permintaan dari luar negeri karena ada begitu banyak perusahaan besar yang membutuhkan pasokan bahan baku kelapa. Total produksi kelapa Sulawesi Utara dapat dilihat pada tabel berikut:

Tabel 1.Total Produksi Kelapa Sulawesi Utara Tahun 2006-2015

\begin{tabular}{ll}
\hline Tahun & $\begin{array}{c}\text { Produksi } \\
\text { (Ton) }\end{array}$ \\
\hline 2006 & $246.262,48$ \\
2007 & $229.613,37$ \\
2008 & $209.994,88$ \\
2009 & $265.451,58$ \\
2010 & $273.234,36$ \\
2011 & $286.352,96$ \\
2012 & $272.480,91$ \\
2013 & $282.500,34$ \\
2014 & $284.330,27$ \\
2015 & $270.036,21$ \\
\hline
\end{tabular}

Sumber:

Badan Pusat Statistik Sulawesi Utara Tahun 2016 (diolah)

Dapat dilihat bahwa total produksi kelapa dari tahun ke tahun mengalami fluktuasi.

\section{Kurs Rupiah terhadap US\$}

Kurs atau nilai tukar merupakan variabel yang paling banyak digunakan dalam penelitiam tentang perdagangan internasional baik ekspor maupun impor. Apresiasi nilai tukar akan mengurangi daya saing ekspor dan meningkatkan impor. Menurunnya ekspor dan meningkatnya impor akan memperburuk neraca pembayaran. Perkembangan nilai tukar Indonesia tahun 2006-2015 dapat dilihat pada tabel berikut :

Tabel 4. Rata-rata Kurs Rupiah terhadap US\$ Tahun 2006-2015

\begin{tabular}{cc}
\hline Tahun & $\begin{array}{c}\text { Nilai } \\
\text { (Rupiah) }\end{array}$ \\
\hline 2006 & $9.166,07$ \\
2007 & $9.136,20$ \\
2008 & $9.679,55$ \\
2009 & $10.394,38$ \\
2010 & $9.083,93$ \\
2011 & $8.779,49$ \\
2012 & $9.380,39$ \\
2013 & $10.451,37$ \\
2014 & $11.878,30$ \\
2015 & $13.391,97$ \\
\hline
\end{tabular}

Sumber : Bank Indonesia (diolah) 
Sejak tahun 2011 nilai tukar rupiah terhadap dollar AS terus mengalami peningkatan. Tahun 2011 rata-rata nilai tukar rupiah $\mathrm{Rp}$. 8.779,49 terus mengalami peningkatan dan tahun 2015 rata-rata nilai tukar rupiah mencapai nilai $\mathrm{Rp}$.

13.391,97. Melemahnya nilai tukar rupiah terhadap dollar Amerika Serikat berpotensi nilai ekspor tepung kelapa dibayar dengan uang dollar Amerika Serikat.

\section{Harga Ekspor Tepung Kelapa}

Harga ekspor merupakan harga jual yang akan dibayarkan oleh importir kepada eksportir . Harga ekspor tepung kelapa merupakan harga yang telah disepakati oleh eksportir dan importir dalam dalam suatu perjanjian atau kontrak. Dalam hal ini, importir boleh menguntungkan ekspor komoditas sektor pertanian. Dalam penelitian ini perusahaan tepung kelapa sebagai salah satu produsen komoditi ekspor pertanian Sulawesi Utara berpotensi untuk meningkatkan ekspornaya. Apabila nilai tukar terus mengalami peningkatan atau rupiah terdepresiasi dan dollar terapresisi maka cenderung meningkatkan ekspor tepung kelapa karena melakukan penawaran terhadap harga yang telah ditentukan oleh eksportir. Apabila harga telah ditentukan bersama atau telah disepakati bersama baik oleh importir ataupun eksportir maka transaksi komoditi atau transaksi tepung kelapa dapat dilaksanakan. Perkembangan harga ekspor tepung kelapa dapat dilihat pada tabel berikut ini:

Tabel 5. Perkembangan Harga Ekspor Tepung Kelapa Tahun 2006-2015

Tahun

Harga Ekspor Tepung Kelapa

(US\$/Kg)

\begin{tabular}{ll}
\hline 2006 & 0,70 \\
2007 & 0,98 \\
2008 & 1,49 \\
2009 & 0,75 \\
2010 & 1,07 \\
2011 & 2,33 \\
2012 & 1,47 \\
2013 & 1,42 \\
2014 & 2,15 \\
2015 & 1,54 \\
\hline
\end{tabular}

Sumber : Dinas Perindustrian dan Perdagangan Sulawesi Utara 
Fluktuasi terhadap harga ekspor ini disebabkan oleh berbagai faktor. Salah satu faktor mempengaruhi harga ekspor adalah pasokan bahan baku. Di Sulawesi Utara ada banyak perusahan-perusahan produk olahan kelapa. Bahkan perusahaan-perusahaan ekspor dengan bahan baku kelapa juga tidak sedikit. Perusahaan ekspor tepung kelapa ada 9 di Sulawesi Utara, yaitu:

\section{PT. Dimembe Nyiur Agripro (DNA) \\ 2. PT. Tina Coconut (POLEKO) \\ 3. PT. Royal Coconut \\ 4. PT. Janur Kawanua Indonesia \\ 5. PT. Tritis Internasional \\ 6. PT. Tropica Coco Prima \\ 7. PT. Tri Mustika Cocominaesa \\ 8. PT. Global Coconut \\ 9. PT. Putra Karangetang}

Sembilan perusahaan tepung kelapa ini bersaing untuk mendapatkan pasokan bahan baku kelapa dari petani. Selain itu, kesembilan perusahaan ini bersaing juga dengan perusahaan-prusahaan dengan bahan baku kelapa lainnya di Sulawesi Utara. Selain perusahaan tepung kelapa, ada perusahaan minyak kelapa, perusahaan kopra, perusahaan bungkil kopra, perusahaan arang tempurung yang merupakan perusahaanperusahaan yang mengekspor produk unggulan di Sulawesi Utara. Ada juga perusahaan lain yang menjual produk dengan bahan baku kelapa yang dijual domestik atai tidak diekspor. Semua perusahaan ini bersaing untuk mendapatkan pasokan bahan baku kelapa. Apalagi tahun 2015, karena musim kemarau yang panjang menyebabkan produksi kelapa menurun.

Selain keterbatasan bahan baku harga ekspor juga dipengaruhi oleh negara tetangga. Negara yang mengekspor tepung kelapa di Asia Tenggara sudah mulai banyak. Vietnam, Kamboja dan Filipina adalah beberapa negara yang mengekspor tepung kelapa. Ketersediaan bahan baku yang besar di negara-negara ini menyebabkan biaya produksi rendah apabila dibandingkan dengan Indonesia khususnya Sulawesi Utara yang biaya produksi tinggi karena harga bahan baku yang tinggi. Oleh karena itu, harga tepung kelapa menjadi turun karena adanya persaingan harga dengan negaranegara tetangga yang juga memproduksi tepung kelapa.

\section{Analsis Regresi Linier Bentuk Ln (Logaritma Natural)}

Untuk mendapatkan model yang baik maka model tersebut harus memenuhi kriteria BLUE (Best Linier Unbiased Estimator). BLUE dapat dicapai apabila memenuhi asumsi klasik. Pengubahan data ke dalam bentuk Ln dimaksudkan untuk meniadakan atau meminimalkan adanya pelanggaran asumsi normalitas dan asumsi klasik. Selain itu, pengubahan ke dalam bentuk Ln ini dimaksudkan untuk melinierkan data. Persamaan regresi linier bentuk Ln adalah sebagai berikut :

$\begin{array}{ll}\quad \text { LNY }^{\prime}=\operatorname{Ln} \beta 0 & +\beta 1 \operatorname{LnX} 1+\beta 2 \operatorname{LnX} 2+\beta 3 \operatorname{LnX} 3 \\ \text { Dimana : } & \\ \text { LnY' } & =\text { Ln Volume Ekspor Tepung } \\ & \text { Kelapa } \\ \text { Ln } \beta 0 & =\text { konstanta } \\ \beta 1, \beta 2, \beta 3 & =\text { koefisien regresi } \\ \text { LnX1 } & =\text { Ln Produksi Kelapa } \\ \text { LnX2 } & =\text { Ln Kurs Rupiah terhadap } \\ & \text { US\$ } \\ \text { LnX3 } & =\text { Ln Harga Ekspor Tepung } \\ & \text { Kelapa }\end{array}$

\section{Uji Asumsi Klasik}

Hasil Output dari Uji multikolinieritas menunjukkan nilai VIF dari semua variabel yang diteliti kurang dari 10. Dari hasil output tersebut dapat disimpulkan bahwa tidak terdapat multikolinieritas pada data yang diteliti atau tidak terjadi korelasi antar variabel bebas pada data yang diteliti.

Hasil pengujian heteroskedastisitas berdasarkan scatter plot (diagram pencar) pada penelitian ini, digambarkan pada Gambar 5.

Berdasarkan diagram pencar pada Gambar 5 dapat dilihat bahwa plot titik-titik menyebar dan tidak membentuk pola tertentu yang jelas sehingga dapat disimpulkan bahwa tidak terjadi heteroskedastisitas.

Hasil output autokorelasi pada estimasi model diperoleh nilai d sebesar 1,509 berada di antara nilai $\mathrm{dL}$, yaitu 0,525 dan nilai $\mathrm{dU}$, yaitu 
2,016. Maka tidak dapat diambil kesimpulan ada atau tidaknya korelasi serial antar residual.

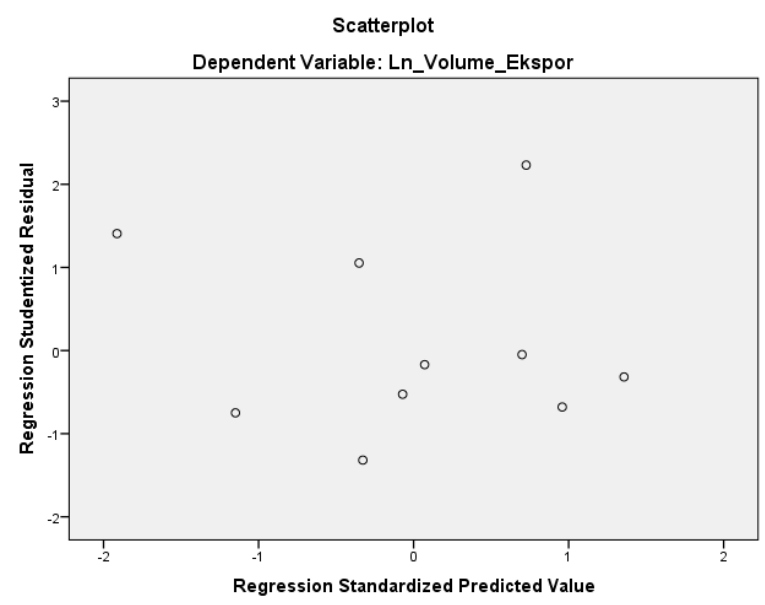

Gambar 5. Hasil Output Grafik Scatterplot

\section{Pengujian Hipotesis}

a. Koefisien Determenasi $\left(\mathrm{R}^{2}\right)$

Hasil output menunjukkan bahwa nilai dari $\mathrm{R}^{2}$ adalah 0,516 hal ini berarti bahwa variabel X1(produksi kelapa), X2(kurs rupiah terhadap US\$) dan X3(harga ekspor) mampu menjelaskan variabel Y(volume ekspor) sebesar 0,516 atau $51,6 \%$ dan sisanya dipengaruhi oleh faktor lain di luar model yang tidak termasuk dalam penelitian ini.

\section{b. Pengujian Secara Simultan (Uji F)}

Hasil dari uji $\mathrm{F}$ menunjukkan bahwa pada periode waktu 2006-2015 variabel produksi kelapa, kurs rupiah terhadap US\$ dan harga ekspor tepung kelapa secara bersama-sama mempengaruhi volume ekspor tepung kelapa Sulawesi Utara. Besarnya variasi volume ekspor yang dapat dijelaskan oleh variabel produksi, kurs rupiah terhadap US\$ dan harga ekspor tepung kelapa sebesar $51,6 \%$. Ini berarti ada sebesar $48,4 \%$ variasi yang dijelaskan oleh variabel lain yang tidak masuk dalam model.

\section{c. Pengujian Secara Parsial (Uji t)}

\section{Produksi Kelapa}

Pengujian secara parsial menunjukkan bahwa pada periode waktu 2006-2015 variabel produksi kelapa berpengaruh secara signifikan terhadap ekpor tepung kelapa Sulawesi Utara. Hal ini berarti bahwa hipotesis ini menolak $\mathrm{H}_{0}$ dan menerima $\mathrm{H}_{1}$ maka produksi kelapa berpengaruh positif terhadap volume ekspor tepung kelapa Sulawesi Utara. Hasil pengujian ini sesuai dengan teori yang dikemukakan oleh Siburian dan kawan-kawan (2014) yang menjelaskan bahwa peningkatan produksi berpengaruh secara positif terhadap penawaran ekspor. Apabila produksi suatu komoditi banyak, maka penawaran terhadap suatu barang akan meningkat sehingga permintaan ekspor akan semakin meningkat. Sebaliknya, apabila produksi suatu komoditi sedikit, maka penawaran akan berkurang yang mengakibatkan ekspor akan menurun. Peningkatan produksi kelapa menyebabkan permintaan terhadap ekspor tepung kelapa semakin meningkat sehingga volume ekspor tepung kelapa akan meningkat.

Produksi merupakan variabel yang sangat penting bagi ekspor suatu komoditi. Permintaan yang besar terhadap komoditi ekspor membutuhkan produksi bahan baku yang besar juga. Ketersediaan bahan baku akan sangat mempengaruhi besarnya kapasitas produksi suatu komoditi dan berimbas pada volume ekspor komoditi tersebut.

Produk turunan kelapa yang begitu banyak membuat kelapa sangat dibutuhkan sebagai bahan baku. Meskipun Sulawesi Utara memproduksi kelapa yang banyak, namun perusahaan-perusahaan bahkan industri-industri yang mengolah produk turunan kelapa juga ada begitu banyak. Hal ini menyebabkan persaingan antar produsen produk turunan kelapa untuk memperoleh bahan baku kelapa menjadi semakin ketat. Apalagi produksi kelapa di Sulawesi Utara belum mampu mencukupi kebutuhan kelapa sebagai bahan baku produk olahan kelapa.

Musim panas tahun lalu menyebabkan produktifitas dan kualitas tepung kelapa menurun. Untuk membuat satu $\mathrm{kg}$ tepung kelapa biasanya dibutuhkan 8-10 buah kelapa. Namun, karena pengaruh dari musim panas kualitas buah kelapa menjadi rendah. Buah kelapa menjadi lebih kecil dan dagingnya menjadi lebih tipis sehingga untuk memproduksi tepung kelapa dibutuhkan buah kelapa sebanyak 12 buah.

Keterbatasan ketersediaan bahan baku ini sangat mempengaruhi kegiatan ekspor tepung kelapa. Meskipun perusahaan berusaha memenuhi permintaan dari luar negeri yang 
besar namun karena kurangnya ketersediaan bahan baku maka produsen tidak bisa menambah produksi dari tepung kelapa. Bahkan apabila produktifitas kelapa menurun maka beberapa perusahaan tidak dapat memproduksi tepung kelapa.

\section{Kurs Rupiah terhadap US\$}

Pada periode waktu 2006-2015 pengujian secara parsial menunjukkan bahwa variabel kurs rupiah terhadap US\$ tidak berpengaruh secara signifikan terhadap ekspor tepung kelapa Sulawesi Utara. Hal ini berarti hipotesis ini menerima $\mathrm{H}_{0}$ dan menolak $\mathrm{H}_{1}$ maka variabel kurs rupiah terhadap US\$ tidak mempengaruhi ekspor tepung kelapa Sulawesi Utara.

Koefisien regresi menunjukkan tanda positif artinya apabila nilai tukar rupiah terhadap dollar menguat atau rupiah terapresiasi maka harga ekspor suatu komoditi akan menjadi mahal. Hal ini menyebabkan permintaan terhadap suatu komoditi ekspor akan menurun (Pambudi, 2011). Sebaliknya, apabila nilai tukar rupiah terhadap dollar melemah atau rupiah terdepresiasi dan dollar terapresiasi maka harga ekspor suatu komoditi akan menjadi murah. Hal ini menyebabkan permintaan terhadap suatu komoditi ekspor akan meningkat.

Sistem pembayaran tepung kelapa menggunakan sistem kontrak. Kontrak dilakukan setiap satu kali transaksi. Hai ini dilakukan karena keterbatasan bahan baku sehingga tidak bisa dilakukan kontrak jangka panjang. Ini berarti bahwa terjadi perjanjian antara pihak yang mengekspor dan yang mengimpor tepung kelapa. Dengan adanya sistem kontrak ini maka telah ada kesepakatan antara pihak penjual dan pembeli.

Kesepakatan ini membuat kurs tidak berpengaruh terhadap ekspor tepung kelapa. Ketika terjadi perjanjian atau kontrak maka pihak pembeli harus membayar sesuai dengan perjanjian yang telah disepakati. Sebesar apapun kenaikan bahkan penurunan kurs rupiah terhadap US\$ tidak akan mempengaruhi ekspor tepung kelapa. Besarnya ekpor tepung kelapa dilakukan sesuai dengan perjanjian yang telah disepakati. Dalam hal ini, importir diuntungkan sedangkan ekportir dirugikan.
Teori ekspor menunjukkan bahwa kurs sangat berpengaruh terhadap ekspor suatu komoditi baik barang maupun jasa. Apabila kurs naik maka ekspor akan meningkat sebaliknya apabila kurs turun maka ekspor juga akan menurun (Froyen dalam Iswanto, 2008), namun dengan adanya sistem kontrak, apresiasi maupun depresiasi kurs rupiah terhadap US\$ sama sekali tidak mempengaruhi ekspor tepung kelapa.

\section{Harga Ekspor Tepung Kelapa}

Output dari uji regresi menunjukkan bahwa pada periode waktu 2006-2015 variabel harga ekspor tidak berpengaruh secara signifikan terhadap volume ekspor tepung kelapa Sulawesi Utara. Hal ini berarti bahwa hipotesis ini menerima $\mathrm{H}_{0}$ dan menolak $\mathrm{H}_{1}$ maka variabel harga ekspor tidak mempengaruhi ekspor tepung kelapa Sulawesi Utara.

Koefisien regresi dari variabel harga ekspor tepung kelapa cenderung negatif. Hal ini sesuai dengan teori hukum permintaan yang mengatakan bahwa semakin tinggi harga suatu komoditi maka semakin rendah permintaan terhadap komoditi tersebut. Sebaliknya, semakin rendah harga suatu komoditi maka semakin tinggi permintaan terhadap komoditi tersebut.

Harga Ekspor memiliki hubungan yang sangat erat dengan nilai tukar atau kurs. Apabila kurs rupiah terhadap US\$ mengalami depresiasi atau dollar Amerika terapresiasi maka akan berpengaruh terhadap peningkatan ekspor dan dalam hal ini juga eksportir diuntungkan. Sebaliknya, apabila kurs rupiah terhadap US\$ mengalami apresiasi atau dollar Amerika terdepresiasi maka ekspor akan menurun dan eksportir dirugikan.

Namun, karena sistem pembayaran dengan menggunakan sistem kontrak maka harga ekspor tidak memiliki pengaruh lagi terhadap volume ekspor tepung kelapa. Harga dan volume ekspor ditentukan atau disepakati pada waktu yang bersamaan sehingga harga ekspor tidak memberikan pengaruh terhadap volume ekspor tepung kelapa Sulawesi Utara. 


\section{KESIMPULAN DAN SARAN}

\section{Kesimpulan}

1. Pada selang waktu 2006-2015 secara signifikan produksi kelapa berpengaruh positif terhadap volume ekspor tepung kelapa Sulawesi Utara.

2. Pada selang waktu 2006-2015 kurs menunjukkan adanya kecenderungan berpengaruh positif meskipun secara statistik kurs tidak berpengaruh secara signifikan terhadap volume ekspor tepung kelapa Sulawesi Utara.

3. Pada selang waktu 2006-2015 harga ekspor tepung kelapa menunjukkan adanya kecenderungan berpengaruh negatif meskipun secara statistik harga ekspor tepung kelapa tidak berpengaruh secara signifikan terhadap volume ekspor tepung kelapa Sulawesi Utara.

\section{Saran}

1. Perlu dilakukan penelitian lebih lanjut mengenai faktor-faktor lain yang mempengaruhi ekspor tepung kelapa Sulawesi Utara seperti GDP negara tujuan, kebijakan pemerintah dan harga internasional tepung kelapa.

\section{DAFTAR PUSTAKA}

Anindita dan Michael, 2008. Bisnis dan Perdagangan Internasional. Edisi Pertama. ANDI, Yogyakarta.

Dave, A. 2010. Kontribusi Ekspor Impor terhadap Pertumbuhan Ekonomi di Indonesia, Bogor

Gujarati. 2012. Dasar-Dasar Ekonometrika. Edisi Kelima. Salemba Empat, Jakarta.

Hamdy. 2001. Ekonomi Internasional: Teori dan Kebijakan Perdagangan Internasional. Edisi Revisi. Ghalia Indonesia.

Iswanto D. 2013. Faktor-Faktor yang Mempengaruhi Ekspor Kayu Lapis Indonesia ke Jepang. Skripsi Universitas Negeri Padang
Kaunang W. 2013. Daya Saing Ekspor Komoditi Minyak Kelapa Sulawesi Utara. Jurnal EMBA Vol.1 No.4 Desember 2013 Universitas Sam Ratulangi, Manado

kemendag.go.id. Diakses tanggal 3 Mei 2015.

Krugman P dan M. Obstfeld. 2000. Ekonomi Internasional : Teori dan Kebijakan. Alih Bahasa: H. Basri. PT Raja Grafido Persada, Jakarta.

Lindert, Peter H. 1994. Ekonomi Internasional. Erlangga, Jakarta.

Muhammad R. 2006. Pengaruh Ekspor, Impor dan Investasi terhadap Pertumbuhan Ekonomi di Kalimantan Timur, Program Magister Ilmu Ekonomi Fakultas Ekonomi, Universitas Mulawarman, Samarinda

Nopirin. 2000. Ekonomi Moneter. Buku II. Edisi I. Cetakan Kesepuluh. BPFE UGM, Yogyakarta.

Pambudi A. 2011. Analisis Faktor-Faktor yang Mempengaruhi Ekspor Biji Kakao Indonesia ke Malaysia dan Singapura. Universitas Diponegoro, Semarang

Rahardja, P dan Manurung, M. 2005. Teori Ekonomi Makro Suatu Pengantar. Edisi Ketiga. Lembaga Penerbit Fakultas Ekonomi Universitas Indonesia, Jakarta.

Salvatore, Dominick. 1997. Ekonomi Internasinal. Edisi Kelima. Erlangga, Jakarta.

Sukirno S. 2008. Makro Ekonomi Teori Pengantar. Edisi Ketiga. P.T Raja Grafindo Persada, Jakarta.

Supranto, J. 2007. Ekonometri. Edisi Satu. Ghalia Indonesia.

Winardi. 2006. Ekonomi Internasional. Erlangga, Jakarta.

www.sulut.bps, go.id diakses pada tanggal 27 Februari 2016. 